\title{
Indang Sungai Garinggiang: The Hybridization of a Popular Image Packagedas a Performing Art in West Sumatra
}

\author{
Surherni, Risnawati Syahri Anton \\ Departement of Dance, Faculty of Performing Art, Indonesian Institute of the Arts, \\ Padangpanjang, Indonesia, 27128
}

\begin{abstract}
This article aims to uncover the subject of Indang Sungai Garinggiang: the hybridization of a popular image packaged as a performing art in West Sumatra. The indang is membranophone, a type of tambourine or rebana (terbangan) which the people of Sungai Garinggiang, Pariaman in West Sumatra call the rapa'i.Indang Sungai Garinggiang is a new performing art genre which is a collaboration - hybridization - of popular dance and music in a commercial form. A qualitative method is used as the basis for this research. The primary data was obtained through a documentary study; the analysis was done descriptively using a theoretical concept, with knowledge of hybridization and popular culture. The results of the research show that Indang Sungai Garinggiang as a popular culture is an arena for the cultural production of 'a battlefield' of two different traditions which recognizes 'authority over the power of domination' - hegemony.
\end{abstract}

Keywords: Indang Sungai Garinggiang, hybridization, popular image, performing art.

DOI: $10.7176 / \mathrm{ADS} / 73-01$

Publication date:May $31^{\text {st }} 2019$

\section{Introduction}

Etymologically, the word indang means a kind of flat basket or tray used for winnowing (Kamus Besar Bahasa Indonesia, 1995: 376). In the Minangkabau dictionary, Yos Magek Bapayuang states that indang is a traditional game played by the people of West Sumatera (anak nagari), usually by groups of young men, who sit close together as they sing pantun (a form of traditional verse), twisting and turning their bodies backwards and forwards while they play tambourines (rapa'i) (Bapayuang, 2005: 159). From a different perspective, Asril describes indang as having two different meanings: first, a musical instrument - a membranophone - in the form of a one-sided drum that the people of Pariaman call a rapa'i (a kind of small tambourine), which is played in interlocking rhythms; second, at the same time as this the indang functions as a medium or a property for dance (Asril, 2017: 35).

In this article, Indang refers to a new genre that was created - made popular - by the creative artists Elly Kasim and Tiar Ramon, and which they gave the name Indang Sungai Garinggiang, in reference to a village (nagari) in the district of Padang Pariaman. The songs of Indang Piaman (Pariaman), which are usually performed either in "solo" form or as a "chorus" in indang style, with the addition of the rapa' $i$, eitherplayed together or separately, use traditional texts that are packaged in the form of popular culture and recorded for commercial purposes - as a popular culture. John Storey describes the pop culture as an arena where hegemony appears, and an area where hegemony transpires (Storey, 2006: 3). John Fiske states that popular culture will always be a part of power relations; of controlling and being controlled - hegemony (Fiske, 2011: 23).

Andar Indra Sastra writes that hegemony is the influence of power on a particular group over the ideology they adhere to in a systematic fashion (Sastra, 2015: 19). Edward Said, in his book Orientalism, states that hegemony is the belief that a particular idea has more influence than another idea, and this makes one culture more dominant than another. In essence, it is no more than a form of legitimation of the superiority of Western culture over the inferiority of Eastern culture (Said, 2010: x).Indang Sungai Garinggiang, whether as dance or music, was created through a process of hybridization from two elements that were 'cross-bred'. If observed from the point of view of cultural change, this hybridization falls into the area of acculturation, which may also be called syncretization or assimilation. However, not all art - music and dance - that is a hybrid can be referred to as a product of acculturation, syncretization, or assimilation, since it first needs to be tested by time and public recognition. The general tendency is to carry out hybridization of a traditional element and a modern or popular culture. This may lead towards the direction of becoming something permanent, as though it has found compatibility with both sides.

From a musical perspective, Indang Sungai Garinggiang can be classed as Minang pop music. Minang pop is a culture which represents the way in which the people of Minangkabau have adapted to the continual changes that are taking place in the world. It is an example of how the recording media has influenced the local Minangkabau culture and transformed the culture and identity of Minangkabau. In his Music Dictionary (Kamus Musik), Ponoe Banu defines music as a branch of the arts which examines and assigns various sounds to patterns that can be understood and comprehended by human beings (Banoe, 2003: 288). Popular means oriented towards the principle of commercialism and produced en masse. R. Middleton writes that popular music has a number of 
characteristics, such as hybridity of tradition ... and is an economic product invested in the ideological interests of a large number of consumers, which reaches a broad audience, and has commercial values (Middleton, 1990: 3) - through the recording industry.

The recording industry in West Sumatra has initiated mediation in the oral arts of Minangkabau while at the same time encouraging the development of Minangkabau pop music and stimulating the creation of genres associated with the media. The recording industry has changed the way the Minangkabau community integrates with its own culture. As the main product of the West Sumatran recording industry with its numerous genres and sub-genres that combine elements of local and foreign music, the image of Minang pop has influenced not only the direction of the development of Minangkabau music but also the musical tastes of the Minangkabau community.

Dendy Sugono et al. in the Indonesian Dictionary (Kamus Bahasa Indonesia, KBI) state that an image is the appearance or picture of a product (KBI, 2008: 290). Indang Sungai Garinggiang represents the product of a hybrid art that is popularized through the media of music and dance. As a dance text, Indang Sungai Garinggiang was created through the creativity of artists by means of a metamorphosis or transformation of the concept of indang tigo sandiang (three-sided indang). Indang tigo sandiang is the formulation of a performance that is made up of three schools of thought or groups (guguih), namely Guguih Kulipah Husein; GuguihKulipah Mak Amuik; and Guguih Kuliah Tan Karim. The words following the term guguih are the names of the caliph whom the particular group follows in an indang performance.

As Ediwar explains, the naming of these three guguih was closely related to the focus of study of each group: guguih kulipah Husein focuses on the prophets and apostles; guguih kulipah Mak Amuik discusses the religious leaders who developed Islam; and guguih kulipah Tan Karim talks about natural events (Ediwar, 1999: 6). Indang Sungai Garinggiang is a transformation of indang tigo sandiang packaged as a performing art. The subject addressed in this article focuses on Indang Sungai Garinggiang and the hybridization of a popular image packaged in the form of a performing art.

The discussion and research on the subject of Indang Sungai Garinggiang: the hybridization of a popular image packaged as a performing art in West Sumatra focuses on a topic that has never before been studied in detail by academic scholars. Previous research and discussions have focused on the change from the surau to a profane form of performing art. Other studies with the art of indang as the material object include an article by Asril (1997: 35), who writes that the performing art of indang is a fusion of the arts of music, dance, and literature. Music is presented in the form of singing (dendang) accompanied by the rhythms of the rapa' $i$ (a small tambourine) which plays interlocking patterns and also functions as an accompanying instrument. The art of dance appears at the same time as the singing, while the text is manifested in the form of verse, pantun, and lyrical prose using a language style of cynicism and sarcasm.

Ediwar (1999: 6) writes about the emergence of three schools/genres (guguih) or groups of indang which are oriented to different focuses of study in Pariaman, namely guguih kulipah Husein which focuses on the prophets and apostles; guguih kulipah Mak Amuik which discusses the religious leaders who developed Islam; and guguih kulipah Tan Karim which talks about natural events. Meanwhile, Nurmalena (2014: 250-251) writes about the dance perspective and the form of performance. In another article, Andar Indra Sastra (2017: 13) discusses the subject of guguih as a representation of the system of the Sufi organization; spiritual genealogyranji - in the organization of tarekat Syatariyah in Minagkabau.

Meanwhile, other literature that is not related to the material object of this study includes the work by John Storey (2006:3), who explains how the pop culture has become an arena for cultural production where hegemony appears, and an area where hegemony transpires (Storey, 2006: 3). John Fiske (2011: 23) talks about popular culture and its relationship with power; controlling and being controlled - hegemony. Arnold Hauser (1982: 580) presents a detailed study of popular culture and popular art. On the aesthetical paradigm, meanwhile, Yulia Kristeva (1989: 69) discusses the hybrid aesthetic in two lines of narration; Yasraf Amir Piliang (2007: 106) explores the use of double coding; Ihap Hassan (1987: 170) opens the discourse about hybridization and the matter of 'cross-breeding' between two cultures.

Edward W. Said (2010: $\mathrm{x}$ ) investigates the philosophical aspect of hegemony in relation to knowledge as a form of power, explaining that one particular idea has more influence than another which makes one culture more dominant than another. In the field of music, R. Middleton (1990: 3) writes that popular means oriented towards the principle of commercialization, and that popular music has a number of characteristics, such as hybridity of tradition ... and is an economic product invested in ideological interests. Meanwhile, Leela Gandhi in Kasyan (Kasyan 2001:24) discusses the subject of colonialism and the crisis of local culture (local genius). Bambang Sugiharto (2002: 134) uses the perspective of postcolonialism and postmodernism to write about hegemony in our space of consciousness. The discussions from this various literature can be used as a reference for the discussion on Indang Sungai Garinggiang: the hybridization of a popular image packaged as a performing art in West Sumatra. 


\section{Research Method}

A qualitative method was chosen for this research because it was considered to be suitable and relevant to the focus of the study. The researcher was the primary instrument directly responsible for collecting data on the material object - Indang Sungai Garinggiang in West Sumatra. The data collection related to the material object was carried out through a documentary study. The primary data obtained through the documentary study was analyzed using the concepts of hybridization and popular culture. In addition, secondary data was also needed to strengthen the argumentation so that the results of the research could reach a level of credibility that could be accounted for scientifically. The data analysis used an etic perspective with theoretical thought concepts that were in touch with the hybridization of a popular image in connection with Indang Sungai Garinggiang as the material object.

\section{Results and Discussion}

\section{Indang Sungai Garinggiang and the Hybridization of a Popular Image Packaged as a Performing Art}

The image of Indang Sungai Garinggiang in the community of West Sumatra is a modern dance genre that was made popular by Elly Kasim and Tiar Ramon during the 1980s. The music that accompanies this dance is known as Dindin Badindin and is packaged in the form of pop music. As a genre of modern dance, it is used as a form of instructional media at various levels of education in West Sumatra. Dindin Badindin was created as a partner for the performance of this dance and is an indicator that music is used to enhance the aesthetical impression of the dance performance. In spite of this, Dindin Badindin is in principle not related to the dance Indang Sungai Garinggiang but is independent and can be appreciated as a music product - in the pop culture - produced by the music industry in West Sumatra - with the community as the consumer.

The consumer of pop culture is not a victim of cultural deception; this is not to deny the fact that at times we may all fall victim to deception. John Storey states that the pop culture is nothing more than a degraded culture that is inflicted from above to make a profit and guarantee ideological control - of cultural production, distribution, and consumption (Storey, 2006: 7). The pop culture is a place where hegemony appears, and an area where hegemony transpires. There is no doubt that ideology is the central concept of cultural studies, working within the framework of Antonio Gramci's concept of hegemony (Storey, 2006: 3).

Indang Sungai Garinggiang as a form of pop culture - dance and music - was created through a process of hybridization which represents an ideological battle between traditional culture and modern culture. To John Fiske, the approach which recognizes pop culture as 'a battleground' nevertheless acknowledges 'authority over the power of domination' (Fiske, 1989: 20). Indang Sungai Garinggiang as a cultural product reflects the occurrence of an ideological battle between traditional culture and modern culture.

The hybrid tendency that is present in Indang Sungai Garinggiang occurs when a form of traditional performing art interacts with another performing art form in a model of 'cross-breeding' between different cultures, texts, forms, and idioms, resulting in new aesthetical categories or a hybrid aesthetic. Tzevetan Todorov writes that a hybrid aesthetic contains "...two remarks, two ways of speaking, two styles, two languages, two semantic and axiological horizons (Todorov, 1984: 73). According to Yasraf Amir Piliang, a hybrid aesthetic builds a kind of textual interfusion through the overlapping of one sign on top of another, through the criss-cross of a variety of forms (Piliang, 2007: 106). A hybrid aesthetic is an expression which contains "...two paths that merge in a single narration (Kristeva, 1989: 69). Indang Sungai Garinggiang displays this kind of tendency; a traditional aesthetic and a modern - pop - culture merge to form a new a new creative genre. Waruwu (2015) in Indra Yudha writes that creative dance is an endeavour to develop a form of dance; wherein the goal is to adapt itself to a new culture or a new system that prevails in society (Yudha, 2017: 155).

Ihap Hassan states that hybridization is the process of creating mutant forms through 'cross-breeding', resulting in a mixed entity that is no longer complete although it still retains part of the identity of the two elements that have been joined together (Hassan, 1987: 170). Hybridization is the use of double-coding in an aesthetical expression, which may contain elements that are different or even conflicting in nature, thus resulting in self-contradiction (Piliang, 2007: 106). This hybrid tendency is apparent in Indang Sungai Garinggiang - the dance text of which originates from the tradition of indang tigo sandiang.

Traditionally, a performance of indang tigo sandiangis presented in group form, according to the different guguih, with each group comprising 8 players, all men. Seven of the players are called anak indang, the other is known as the tukang dikia, and all sit cross-legged in a row. Asril explains that the anak indang are all the players who sit cross-legged in a row at the front with their legs touching. They include thetukangaliah (alih)/tukangkarang;tukangapik (apit); tukang pangga (penggal); and the tukangpalang (pelang) - (Asril, 2017: 13). In general, they all function as singers, rapa'i players, and "dancers".

The tukangaliah/tukangkarang sits in the middle of all of the indang players and his role is: first, as the main assistant to the tukang dikia in composing the story; second, to give a cue to the other anak indang when the performance is about to begin; third, to begin and end the performance; fourth, to determine the rhythmic patterns of the rapa' $i$ - pola darap or interlocking patterns; fifth, to change songs and determine the movements. 
The position of the tukangaliah/tukangkarang is in the middle of the anak indang. The tukangapik (apit) are the two players who sit on either side of (mengapit) the tukang aliah. One of the tukang apik plays variations on the sounds of the rapa' $i$ played by the tukang aliah, while the other plays variations on the patterns played by the first tukang apik. The two tukang pangga sit to the left and right of the tukang apik. Their role is to follow the patterns of the second tukang apik. The tukang palang sit on the far right and far left of the group. Their patterns match those of the second tukang apik. The tukang dikia is the main figure in an indang performance; he sits directly behind the tukang aliah and is the solo singer who presents stories about the prophet or the characteristics of God, accompanied by the anak indang.

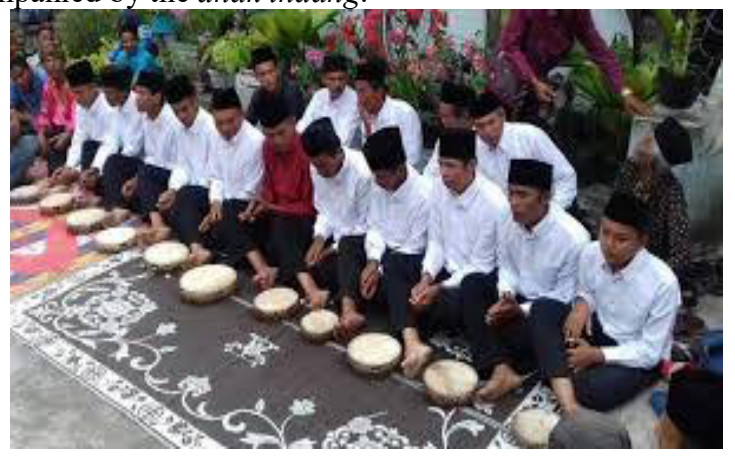

Picture 1.Performance of traditional indang in the Pariaman community

(Photo: Documentation by Surherni 2017)

The photo above shows a traditional indang performance; the anak indang may comprise 7, 9, or 11 people - all adult males. If there are 9 anak indang, the two players on the far left and far right of the group function as the tukang palang. Similarly, if there are 11 anak indang, the three players on the far right and far left function as the tukang palang.Meanwhile, inIndang Sungai Garinggiang, all of the players - who may be male or female - sit in rows while they play the rapa' $i$ and dance. The roles of tukangaliah/tukangkarang,tukangapik, tukang pangga, and tukangpalang no longer exist.

Additionally, Indang Sungai Garinggiang is performed as an attractive dance and its storyline can no longer be identified by interpreting the texts that are sung - narrated - by the dancers to accompany their dance movements. Instead, the function of the texts is to provide entertainment (see the pantun below).

Balari-lari bukanyo kijang (running is it not a deer)

Pandan tajamua di muaro (pandanus drying in the sun at the estuary)

Kami manari basamo-samo (we dance together)

Paubek hati dunsanak sadonyo (consoling the hearts of all)

Ikolah indang Sungai Garinggiang (this is Indang Sungai Garinggiang)

Kami tarikan basamo-samo (we dance it together)

Sambuiklah salam oi sambah mairiang (welcome the greetings accompanied by homage)

Pado dunsanak alek nan tibo (to all who come to the celebration)

Bamulo indang ka ditarikan (beginning by dancing the indang)

Salam bajawek (ondeh) ganti-baganti (greeting each other (ondeh) in turn)

Lagu lah indang kami nyanyikan (the song of indang we sing)

Supayo sanak (ondeh) basuko hati (so that you (ondeh) are happy)

Dindin badidin oi dindin badidin (dindin badidin ai didin badidin)

Dindin badidindin oi dindin badindin (dindin badidin ai didin badidin)

The text of Indang Sungai Garinggiang shown above no longer provides a picture of the story such as in a performance of indang tigo sandiang - it is a form of performing art that functions purely as entertainment. In addition to acting as a continuation of existing forms, Indang Sungai Garinggiang has also experienced change a process of hybridization. The changes that have been made include shortening the time used for dancing. The consequence of a shorter duration is that it leads to more concise dance movements. This condition is evident in performances of Indang Sungai Garinggiang that are packaged for entertainment purposes and have been reduced to a shorter length. Another change is in the costumes worn, which no longer follow the original tradition. Meanwhile, the music - Dindin Badindin - originates from the narration of Minangkabau literature and is packaged in the form of 'Minang pop' which has been specially composed to accompany the indang dance (see photo below). 


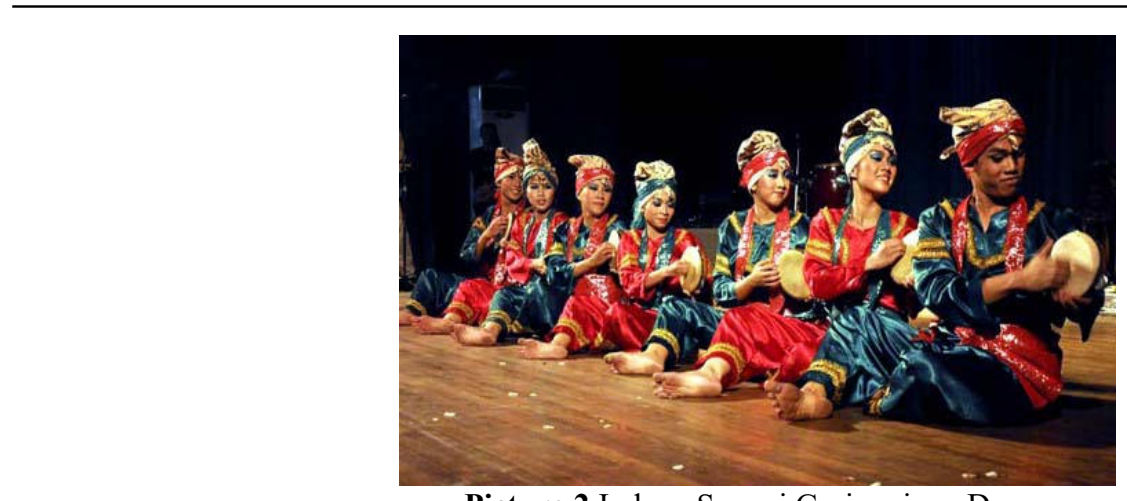

Picture 2.Indang Sungai Garinggiang Dance

(Photo: Documentation by Surherni 2017)

The photo above shows an Indang Sungai Garinggiang performance by 7 female performers. This dance has undergone an adaptation and transformation from indang tigo sandiang. The indang dance and Dindin Badindin music together form a performing art which is the merging of two paths in a single narration traditional and modern.Based on this reality, the philosophical imperative that can be made is that questioning the possibility of the revitalization of local cultural wisdom, including specifically in this context what is taking place in Indang Sungai Garinggiang, is a task which demands complex and comprehensive examination, both related to external and internal aspects. The external domain is closely related to how we respond to the various problems surrounding the colonization and modernization of world culture, the dialectic of which can never be separated from the influence of Western culture. Koentjoroningrat, (2000) inPanakajaya Hidayatullah, states that the domination and power of hegemony force a community to follow and accept every aspect of its culture including music (Hidayatullah, 2017: 4).

On an internal level, there is at least a need to prioritize an auto-critical process related to the possibilities of latent weakness contained in our own culture - although in the past relatively few parties have been concerned with questioning this aspect. Leela Gandhi in Kasian writes as follows:

There are many views which reveal that the reality of the crisis of local genius, especially in

Eastern nations - including Indonesia - are externally caused by the injustice of the dialectic with the cultures of Western nations. This dialectical injustice, if traced clearly, is ultimately closely bound to the problem of colonialism. Although the physical colonialism of Western nations that was experienced by the majority of Eastern nations ended around the middle of the $20^{\text {th }}$ century, substantively the era of colonialism has not vanished from the room of civilization. It is apparent that colonialism did not end when colonial occupation ended (Kasian 2001:24).

Furthermore, Kasian explains that after physical colonialism ended, the deployment of the operation of colonial power changed its face, no longer using ways of violence but instead influencing mental consciousness through ideological cultural determination (Kasyan 2001:26). In this context, Bambang Sugiharto writes that it is equally important that because the practice of postcolonialism and postmodernism did not appear coercively but hegemonically in the space of our own consciousness, it has ultimately become the configuration of our own face; we wish to be modern with all the technical-material facilities and pleasures modernity offers. Therefore, instead of regarding them as colonial, the colonial powers are viewed as a saviour whose presence is missed (Sugiharto, 2002: 134). As stressed bySuharji inJurnal Harmonia, performing arts [dance] are used as a place for an interlude in political space, a discursive discourse ... because people are still able to appreciate dance without feeling hegemony (Suharji, 2017: 196).In this context, Lyotard, as quoted by Daud Aris Tanudirjo in Humaniora, writes that: "Post-modern knowledge is not simply a tool of authority; it improves our sensitivity to difference and strengthens our ability to tolerate things that are not comparable (Tanudirjo, 2017: 6).

With the increasing complexity of the various problems which surround the existence of local culture as a form of identity, the alternative outlets offered do not promise much choice, apart from having to be placed within a comprehensive framework that has the ability to touch numerous domains. The approaches that are able to promise this direction include postmodernism and postcolonialism. Both of these have similarities and relevance, as discourse which questions the central matter concerning colonialism, namely a spirit of opposition and freedom. This condition can be examined through the popular image of an Indang Sungai Garinggiang performance which is a hybridization of tradition on the one hand and modern culture on the other. Deridda in Kasyan states that one characteristic of the paradigm of postmodernism and postcolonialism is the celebration of awareness of difference, which also means positioning local culture, whether in the context of micro-ethnicity or the macro nation state, with the potential for an equal position (Kasyan, 2001: 20). Andar Indra Sastra in Humaniora writes that the emergence of the concepts of modern dance and talemponggoyang (a popular art) indicate the social phenomena and social conditions of the community - the mentality of the community - as a 
consequence of colonialism and the subsequent behaviour known as postcolonialism (Sastra, 2017: 251).

A popular image is the process of formation of a product - in this case with Indang Sungai Garinggiang as the material object - with an economic orientation. Indang Sungai Garinggiang as a genre of modern dance and Dindin Badindin as a category of pop music are inseparable in the context of a performing art. Nevertheless, as a piece of music, Dindin Badindin can appear independently and is a part of the genre of Minang pop music. Both of these categories have emerged as a form of hybridization - of music and dance - sourced from two different traditions - with local and foreign elements. Popular music is inclined to be viewed as art that has deviated from an established cultural pattern. It is no longer merely entertainment but has also become an arena for business, a place to find popularity. Fiske's approach to pop culture [music], as quoted by John Storey, is an approach which recognizes culture as 'a battleground', although it acknowledges 'authority over the power of domination' (Storey, 2006: 33). A battleground emerges from two different sources of narration - traditional and modern.

Indang Sungai Garinggiang represents the product of a hybrid art that is popularized through the media of music and dance. Popular culture in an industrial community is a contradiction to its resources. John Fiske states that the popular culture created by a community is not produced by the cultural industry. The cultural industry can only produce the repertoire of texts (dance and music) to be used or rejected in an ongoing process in producing their popular culture (Fiske, 2011:26). On one hand, this culture is industrialized by an industry that is motivated by profit directed by economic interests. However, on the other hand, this culture is the culture of a community - where an attitude of ambivalence exists. Norita N Sembiring in Budiawan (ed.) writes that this attitude of ambivalence on one hand rejects the influence of modern culture because it destroys tradition, but on the other hand it accepts various forms of progress that are promising (Sembiring, 2010: 76).

Indang Sungai Garinggiang as a cultural product - dance and music - belongs to the category of popular art. Arnold Hauser describes popular art as a product of a form of urban life that is restless and hungry for sensation (Hauser, 1985: 580). The crime of popular art does not originate from the desire to produce attractive works ... but rather from the readiness of the artist to make compromises without hesitation and descend to a lower level in order to achieve success (Hauser, 1985: 581) - popularity and economy.

The lexical definition of the word "popular" is a quality that conforms to the understanding, tastes, and needs of a broad strata of society, and this suits the description of popular art very well. Arnold Hauser also writes that popular art is a product of the entertainment industry, a creation that is developed consciously and is managed carefully by a group of business people who fund its production and distribution (Hauser, 1985: 648). Popular art is high art with damaged "morals"; the enjoyment of popular art is literally an enjoyment that exists in the domain of aesthetics, such as the majority of economic consumption.

As a form of popular art - dance and music - Indang Sungai Garinggiang has succeeded in increasing the popularity of Elly Kasim and Tiar Ramon, the artists who popularized it in West Sumatra. This popularity had an economic impact for both the producers and the artists, through the sales of audio cassettes and video CDs which were explored up to a level of total saturation. In qualitative terms, the level of popularity of the Indang Sungai Garinggiang dance can be seen in educational institutions in West Sumatra. The Indang Sungai Garinggiang dance is always used as a form of instructional media for students at elementary and high school level in West Sumatra through extracurricular education.

\section{Conclusion}

Indang Sungai Garinggiang is a genre of modern dance which was created through a process of adaptation and transformation of indang tigo sandiang; which genealogically has grown and developed within the culture of the Padang Pariaman community in West Sumatra. The transformation is based on the principle of change with a touch of the concept of hybridization and the dual narration of traditional and modern it contains. The "crossbreeding' of the two has given birth to a new generation in the tradition of performing arts in West Sumatra. Indang Sungai Garinggiang is the representation of a hybrid art that has been popularized through the media of music and dance.

As a popular culture, Indang Sungai Garinggiang has become an arena for cultural production, a 'battleground' for two different traditions which acknowledges 'authority over the power of domination' hegemony. Popular culture is created by a community in connection with the products of its cultural industry and day to day life. As a popular art, Indang Sungai Garinggiang is an image of a form of urban art; a product of the entertainment industry.

\section{References}

Asril, (1997). "Seni Pertunjukan Indang Pariaman Minangkabau, Pergeseran dari Relegius ke Profan". Jurnal Seni Budaya ASKI Padanganjang.Volume 1.Nomor 1, Tahun 1, 11 Maret 1997: 35-48.

------, (2017). Adu-Tanding: Konsep Seni Pertunjukan Tradisi Dan Ritual Masyarakat Pariaman. Orasi Ilmiah. Disampaikan Dalam Rangka Dies Natalis Ke-52 Institut Seni Indonesia Padangpanjang.

Banoe, P. (2003). Kamus Musik. Yogyakarta: Penerbit Kanisius. 
Ediwar. 1999. "Perjalanan Kesenian Indang Dari Surau Ke Seni Pertunjukan Rakyat Minangkabau Di Padang Pariaman, Sumatera Barat". Tesis.Program Studi Seni Pertunjukan Jurusan Ilmu-ilmu Humaniora. Yogyakarta: Program Pascasarjana Universitas Gadjah Mada.

Fiske, J. (1989). Undestanding Popular Culture. Boston: MA. Unwin Himan. -, (2011).Memahami Budaya Populer. Terje.Asma Bey Mahyudin. (Understanding Popular Cultrure). Yogyakarta: Jalasustra.

Gandi, L. (2001). Teori Poskolonial Upaya Meruntuhkan Hegemoni Barat. Terj.Wahyutri \& Nurhamidah. Yogyakarta: Kalam'.

Hassan, I. (1987). The Postmodern Turn: Essays in Posmodern Theory and Culture. Ohio State University.

Hidayatullah, P. (2017). The dynamic phenomena of strékan music from colonial tocontemporary era in Situbondo.Harmonia Journal of Arts Research and Education.17 (1) (2017): 1-12.

Indrayudha.dkk. (2017). Women domination in the Galombang dance: between thecustomary idealism and the market use. Harmonia: Journal of Arts Research and Education. 17 (2) (2017): 153-162.

Kristeva, Y. (1989). Desire in Language: A Semiotic Approch to Literature and Art. London: Basil Balcckwell.

Sembiring, N (ed.). (2010). Ambivalensi Post-Kolonialisme Membedah Musik Sampai Agama Di Indonesia. Yogyakarta: Jalasutra.

Sugiharto, B. (2002). Sejarah, Ruang, Imajinasi, dalam Essay-Essay. Bentara Jakarta: Buku Kompas.

Sugono, D dkk, (2008).Kamus Bahasa Indonesia. Jakarta: Pusat Bahasa Departemen Pendidikan Nasional.

Middleton, R. (1990). Studying Popular Music. Milton Keynes: Open University Press.

Said, E. W. (2010).Orientalisme: Menggugat Hegemoni Barat dan Mendudukan Timur Sebagai Subjek. Terje. Achmad Fawaid (Orientlism). Yogyakarta: Pustaka Pelajar.

Sastra, A.I. (2015). Estetika Hegemoni Talempong Pacik di Sumatera Barat.Mudra Jurnal Seni Budaya.Volume 30. No. 1 Februari 2015: 18-36.

------------, (2017).Postcolonial Aesthetics: Talempong Kreasi and Talempong Goyang in West Sumatra. Jurnal Humaniora. Volume 29. Namber 3 Oktober 2017 (245-255).

Storey, J. (2006).Cultural Studies dan Kajian Budaya Pop.Terje.Laily Rahmawati.Cultural Studies and The Studi of Popular Culture: Tehories and Methods. Yogyakarta: Jala Sutra.

Tanudirjo, D. A. (2017).Reflection on the Production of Knowledge:From Postmodernism to Pseudoscience. Jurnal Humaniora. Volume 29. Namber 1 Februari 2017 (3-11).

Todorov, T. (1984).Mikhail Bakhtin: Dialogical Principle. Mancester University Press.

Piliang, Y. A. (2007). Seni Pertunjukan Tradisi dalam Peta Seni Pos-modernisme.Panggung: Jurnal Seni Budaya. Vol. 17. No. 2 Juni-September 2007: 100-111.

Suharji. (2017). Bedhaya Bedhah Madiun dance:As a tourism superior asset in puro Mangkunagaran.Harmonia: Journal of Arts Research and Education. 17 (2) (2017): 190-198. 